REVIEW ARTICLE

\title{
Prospects of American Oil Palm (Elaeis oleifera, HBK) Germplasm and Interspecific Hybrids in India
}

\author{
Murugesan $\mathbf{P}^{* 1}$, Rethinam $\mathbf{P}^{2}$ and Masilamani $\mathbf{P}^{3}$ \\ ${ }^{* 1}$ ICAR-Indian Institute of Oil Palm Research, Research Centre, Palode, Pacha, Kerala - 695562. \\ (*1Presently, Central Tuber Crops Research Institute, Sreekariyam, Thiruvananthapuram, Kerala- 695 017) \\ ${ }^{2}$ ICAR-Indian Institute of Oil Palm Research, Pedavegi, Andhra Pradesh-534 450. \\ ${ }^{3}$ Anbil Dharmalingam Agricultural College and Research Institute, TNAU, Trichy - 620009.
}

Received : 21 ${ }^{\text {st }}$ February, 2020

Revised : $26^{\text {th }}$ February, 2020

Accepted : $12^{\text {th }}$ March, 2020

\section{ABSTRACT}

Unlike African oil palm (Elaeis guineensis, Jacq.), American oil palm (Elaeis oleifera, $\mathrm{HBK}$ ) has unique traits such as reduced height increment, palm oil with significantly high oleic acid, carotene and tocotrienols. However, a pure stand of oleifera is not cultivated and has inherent abnormalities in reproductive structures, which lead to poor fruit set. To overcome these, oleifera is backcrossed to guineensis $(\mathrm{O} \times \mathrm{G})$ through interspecific hybridization (IS). Genetic diversity studies indicated that there are four geographically distinct populations of a pure stand of oleifera distributed in Brazil, Peru, Central America/North Colombia, and Surinam/French Guiana. Oleifera germplasm has been collected from above natural palm grooves and conserved in the field gene banks of oil palm growing countries. Advanced $\mathrm{O} \times \mathrm{G}$ hybrids were developed with a major breeding objective of improving palm oil quality and high-density planting. Some advanced $O \times G$ hybrids are reported to produce high oil yields close to that of tenera of African oil palm. The interspecific hybrids namely, BRS Manicore, PS4, AA Hybrida IS, \#S (\& \#D), Amazon, Taisha, Sinu-Coari $\times$ Coari from EMBRAPA (Brazil), Malaysian Palm Oil Board (Malaysia), Applied Agricultural Resources (Malaysia), Palmelite (Formerly CIRAD, France), Agricultural Services and Development (Costa Rica), Instituto Nacional de Investigaciones Agropecuarias (INIAP), Ecuador and Peru, respectively are important examples for $\mathrm{O} \times \mathrm{G}$ hybrids. There are four oleifera accessions, namely, DOPR22, DOPR23, DOPR24, and DOPR25 available in India. Four genetic stocks viz., Palm no.45 of Surinam of DOPR22, Palm No.6 of DOPR23, Palm No 48 of DOPR23, and Palm No.6 of DOPR25 were developed for improvement and introgression into Indian breeding programme. Oleifera genetic resources and $\mathrm{O} \times \mathrm{G}$ hybrids have good prospects for achieving high oil quality, disease tolerance/resistance, and suitable for high-density planting. India has a very narrow genetic base, and there is an urgent need to collect new materials from centers of origin by exploration and exchange through unilateral and multilateral collaborative research programmes.

Keywords: Elaeis oleifera, germplasm, interspecific hybrids, palm oil quality, India

\section{INTRODUCTION}

Oil palm is a strategically important crop to the world, and it is essential for India in view of everincreasing demand for edible vegetable oil and their industrial utilities (Rethinam et al., 2012, Chadha, 2006, Renjini and Jha, 2019). The cultivated type, Elaeis guineenis originated from West and Central Africa whereas, its wild relative Elaeis oleifera (HBK) originated from South America (Rey et al., 2004) distributed between $11^{\circ} \mathrm{N}$ and $15^{\circ} \mathrm{S}$ (Andrade, 1983 and Corley and Tinker, 2003) and it can be differentiated from African oil palm (Elaeis guineensis, Jacq) by dwarf and slant trunk (Corley and Tinker, 2003). E. oleifera has important traits such as reduced height increment (Barcelos et al. 2000) (10-15 cm per year), tolerance to pest and disease, high quantity of unsaturated fatty acid, carotene (Choo et al., 1997 and Choo et al., 1996) and vitamin E (Corley and Tinker 2003) and Rocha, et al. (2006). It is to be noted that canola oil has the number one rank in terms of concentration of unsaturated monounsaturated fatty acids (61\%) whereas soybean, sunflower, and African oil palm has $22 \%, 29.8 \%$ and $52.1 \%$ of unsaturated and 
monounsaturated fatty acids, respectively. Liquid or fluidity is more, if palm oil possesses high oleic acid (unsaturated) (Omorefe Asemota and Farida Habib Shah, 2004). The palm oil of E. guineensis contains approximately $50 \%$ of saturated fatty acids, with $44 \%$ of palmitic acid (C16:0), $5 \%$ of stearic acid (C18:0), and trace amounts of myristic acid $(\mathrm{C} 14: 0)$. The unsaturated fatty acids are about $40 \%$ of oleic acid (C18:1) and $10 \%$ of polyunsaturated linoleic acid (C18:2) and linolenic acid (C18:3) (Sambanthamurthi et al., 2000). Whereas Elaeis oleifera has an average of $50.10 \%$ monounsaturated fatty acids, which is two percent lower than African oil palm. Elaeis oleifera also has lower saturated fatty acid $(33.5+0.5)$, while normal oil palm has slightly more $(47.3+0.1)$. The fatty acid, palmitic acid, (C16:0) is predominantly present in guineensis, whereas, in E. oleifera, oleic acid, (C18:1) is a predominant fatty acid. Elaeis oleifera produces oil with high carotene content of about 4000 ppm compared to $500-700$ ppm in Elaeis guineensis. The mesocarp oil and fatty acids extracted from African and American oil palms are used in the cosmetic and biofuel industries (Corley, 1982). African oil palm is reported to grow vigorously about $60 \mathrm{~cm} /$ year, whereas oleifera shows an average height increment of 10-15 cm/year. Despite several desired features, pure oleifera stand has some bottlenecks viz., protracted anthesis duration, poor fruit set differences in ripening, and higher percentage of parthenocarpy fruits. These undesirable traits were reported by Rao and Chang (1982). Wiart and Gascon (1975) and Noiret and Wuidart (1976) confirmed that the main source of high levels of unsaturated fatty acids (60 to $75 \%$ ) is E. oleifera. Modern oil palm breeding aims to increase the unsaturated fatty acid content of palm (Arasu et al., 1987). Though, Indian oil palm industry is still in the infant stage it is expected that advanced indigenous technological interventions will bring positive changes. High cost towards harvesting and disease incidence too affects oil palm cultivation (Prasad, 2018). Identification of superior parents and progenies will give raise to superior quality and favors growth of agro industry (Kanimozhi et al., 2018). A total of 1.93 million ha in 18 states has been identified as a potential area suitable for oil palm. About 2, 31,000 hectares are already under oil palm cultivation, of which Andhra Pradesh alone possesses 1, 27,000 ha (2012-13) (https:// nmoop.gov.in). The states where there is maximum potential for oil palm cultivation are Andhra Pradesh, Karnataka, Tamil Nadu, Maharashtra, and Odisha. There is also bright scope to expand oil palm cultivation in the North-Eastern regions of the country (https://nmoop.gov.in). Considering the requirement of new varieties and limited availability of germplasm, all-out efforts must be undertaken for the collection of new germplasm, conservation, and effective utilization for the development of new varieties suitable for different agro-climatic conditions. In the present article prospects of oleifera germplasm and interspecific hybrids are reviewed with major emphasis to India

\section{MATERIALS AND METHODS}

\section{Elaeis oleifera genetic resources}

Elaeis oleifera is considered one of the precious genetic resources to overcome some of the problems being faced by oil palm industry. Dwarf palms facilitate easy to harvest (Diana Arias et al., 2015; Murugesan et al., 2011). The Elaeis oleifera is naturally found in South, Central America, from Honduras to Colombia and in the Amazon region (Raja Naidu, 1983). Researchers from various oil palm growing countries have collected $E$. oleifera germplasm and established field gene banks in Malaysia, Ivory Coast, Costa Rica, Brazil, and Colombia etc. The major players involved in oil palm collections in the primary centers of origin are MPOB (Malaysia), CIRAD (France), CENIPALMA (Colombia), EMBRAPA (Brazil), CNRA (Ivory Coast), INRAB (Benin), IRAD (Cameroon), ASD (Costa Rica) and INIAP (Instituto Nacional de Investigaciones Agropecuarias, Ecuador and others. Oil palm is cultivated in Brazil in the state of Pará located in the north. This region holds $80 \%$ of the Brazilian oil palm fields. $0 \times G$ hybrid was mainly introduced here to reduce the incidence of bud rot (Chia et al., 2009). In the Amazon forest, E. oleifera populations are usually found near rivers, on fertile and welldrained lands (Moretzsohn et al., 2002). The molecular marker study revealed that there are four geographically distinct populations distributed in Brazil, Peru, Central America/North Colombia, and Surinam/French Guiana. The research findings of Araya et al., (2009) and Barcelos et al., (2002) confirmed the status of four geographically distinct populations of oleifera in the South American continent. Digner Ortega Cedillo et al., (2016) studied and confirmed significant variation from accessions of oleifera in Ecuadorian Amazon. Extensive E. oleifera germplasm collection was also carried out in Latin America by Malaysia (Rajanaidu 1986). The performance of Elaeis oleifera from Panama, Costa Rica, Colombia and Honduras planted during 1982 were evaluated in Malaysia and reported significant differences for fatty acids compounds (Mohd Din et al., 2000). Rajanaidu et al., (1989) reported details of fatty acid components of $\mathrm{O} \times \mathrm{G}$ hybrids of South American germplasm collections in Malaysia, which are conserved in the field gene bank. It is reported that the 'oleifera' found in Surinam is unique with very slow vertical growth and small inflorescence and high saturated fatty acid profile under Malaysian 
condition (Rao et al,1989). Surinam source of germplasm is not only diverse but also unique which deserves immediate attention for gene pool conservation (Corley and Tinker, 2003). Hardon (1969) demonstrated that there are significant differences between the species Elaeis oleifera and Elaeis guineensis regarding the content and type of fatty acids present in their oils. Wei Xia et al., (2019) assessed fatty acid compounds in 200 genotypes and recorded 31.3 to 48.8 -of palmitic acid, 31.3 to $50.1 \%$, of oleic acid, 7.1 to $18.5 \%$ linoleic acid with total oil content of 29.8 to $70.3 \%$. A total of 175 accessions of $E$. oleifera collected from the Amazon River basin were assessed for genetic diversity, and most of the variations were observed withinpopulation, which confirms allogamous nature of perennial species (Moretzsohn et al., 2002). Oleifera in situ characterization from Amazonian Trapezoid collected by Cenipalma revealed high variation in vegetative characteristics and bunch components. The values in ranges for unsaturated fatty acid, lodine Value, carotene content and Vitamin E are $68-73.5 \%, 76.4$ to $84.5,1880-6527 \mathrm{ppm}$, 519 to $1140 p p m$, respectively (Rey et al., 2004). Barcelos et al., (2005) highlighted the presence of traits responsible for the drought, waterlogging, and nutrient deficiency management in oleifera germplasm. Hence, the collection and conservation of germplasm should be further intensified to prevent the extinction of diverse and wild relatives.

\section{RESULTS AND DISCUSSION}

\section{Interspecific hybrids}

American oil palm is the main source of genetic variability for oil palm breeding. Despite desirable qualities, cultivation of pure stand of $E$. oleifera is not viable economically, due to its low yields $(<1.0$ tonne oil/ ha/year) compared to E. guineensis (4-5 tonnes oil/ ha/year). Since two species hybridize easily, interspecific hybrids could be obtained with yields around $90 \%$ of the E. guineensis (Amblard et al., 1995). To introgress traits of oil quality and low height increment from E. oleifera into E. guineensis, two species are hybridised (Hardon and Tan, 1969) to produce oleifera $\times$ guineensis $(\mathrm{O} \times \mathrm{G})$ hybrids. Subsequently, $\mathrm{O} \times \mathrm{G}$ hybrid is backcrossed to its selected $E$. guineensis parent to improve the yield. The hybrid between above two $O \times G$ hybrid is nowadays suggested for specific situations like bud rot infested area (Torres et al., 2010) and high-density planting etc. Replanting of $\mathrm{O} \times \mathrm{G}$ hybrids is also undertaken by some oil palm countries in view of catastrophic bud rot disease spread in South African countries (De Franqueville 2003). The palm with a high content of unsaturated fatty acids attracts a new market for growers (Montoya et al. 2013). BRS Manicoré is the first national $\mathrm{O} \times \mathrm{G}$ hybrid developed by EMBRAPA
(Cunha and Lopes, 2010). First reported F1 hybrids were from Oil Palm Genetics Laboratory, Johor, Malaysia, during 1969. Malaysian Palm Oil Board has developed a hybrid, namely PS 4 enriched with palm oil with high carotene content utilized from Elaeis oleifera germplasm (Mohini et al., 2002). Malaysia has developed an oil palm hybrid with high oleic acid (approximately 52\%) (Rajanaidu et al., 2017). A company, namely, Applied Agricultural Resources Sdn. AAR, Malaysia has an exclusive breeding programme of $E$. oleifera that resulted in the creation of the AA Hybrida IS. Interspecific hybrids are commercially produced for local and overseas markets (Abdul Rahim et al., 2017) under a favorable growing environment, a maximum of 35 tonnes of fresh fruit bunch and 8-9 t of crude palm oil per hectare is reported in Hybrida1 during 7-10 years after planting. Hybrid seeds of $\mathrm{O} \times \mathrm{G}$ are produced through bi-clonal seed production system. Another France based company called Palmelite (formerly known as CIRAD) developed interspecific hybrids with premium oil quality (low lipase and acidity) and high-density planting (Legen et al., 1991). Some improved interspecific hybrids found to exhibit slow fruit detachment even after full ripe maturity (Ochoa et al., 2013). The produce, namely '\#S' and \#D denoted for dwarf and high-density hybrids, respectively. The '\#S' have $46-50 \mathrm{~cm}$ of height increment year ${ }^{1}$ with 26- 28\% Industrial Extraction Ratio (IER) of CPO and 160 palms population hectare ${ }^{-1}$ can be accommodated for '\#D'. One $\mathrm{O} \times \mathrm{G}$ hybrid 'Amazon' (with high oil quality) developed by ASD Costa Rica (South America) can accommodate 135 palms in a hectare of land (Alvarado and Escobar, 2016). Amazon was developed from the oleifera germplasm collected from Manaos region of Brazil (Murugesan and Sunil Kumar, 2014). It is reported that $\mathrm{O} \times \mathrm{G}$ hybrids developed from Taisha (Ecuador) had the potential to produce high oil yields close to that of dura $\times$ pisifera (tenera) seeds of E. guineensis. There are indications that interspecific hybrid ( $E$. guineensis $\times E$. oleifera) presents tolerance to drought, waterlogged soils and nutrient deficiency (Barcelos et al., 2005). Moreover, some selected interspecific hybrids (Deli $\times$ Yangambi NIFOR) were found to have slow fruit detachment (Ochoa et al., 2013); lower lipase activity and slow development of free fatty acids in oil (Cadena, 2013). Promising four back crossed families (sourced from South American countries) were developed from United Plantation Berhad, Malaysia, capable of fresh fruit bunch yield up to 35 tonnes/ha/year in the second year of harvest with oil/ bunch ratio of 32 percent and oil yield potential of 10 tonnes/ha/ year. Selection of ortets from these back crossed progenies are under progress with an objective to develop compact clones and seed progenies with 6.25 per cent $E$. oleifera traits. Such hybrids are

$107|1-3| 10$ 
amenable to high-density planting of 200 palms/ ha compared to conventional $136-160$ palms/ha. An interspecific hybrid from Peru namely, Sinu-Coari $\times$ Coari $\times$ La me had a higher capacity of $\mathrm{Co}_{2}$ fixation coupled with desirable agronomic performance (Rivera et al., 2013). Ibarra-Ruales and Reyes-Cueta (2015) reported that $0 \times G(F 1)$ hybrid showed vigorous growth and accumulated more biomass (when compared to normal tenera hybrid) in the plant parts maintained in the nursery in Colombia. The popular interspecific hybrids of CENIPALMA of Colombia, namely Coari $\times$ Lame $(\mathrm{O} \times \mathrm{G})$ hybrids, had mean lipase enzyme activity ranged between 28.5 to 38.6 Free Fatty Acid, whereas E. quieensis and E. oleifera recorded lipase value of $52.7 \%$ and $0.6 \%$, respectively (Cadena et al, 2013). Preciado et al., (2011) predicted the ripeness period of $O \times G$ hybrid and obtained high oil extraction between 170 and 180 days after artificial pollination. Similarly, Rincon et al., (2013) obtained optimal harvest stage coinciding with high oil content at stage 807 in hybrid Coari $\times$ Lame and estimated to take 204 days to complete fruit ripening up to senescence. Phenology of $\mathrm{O} \times \mathrm{G}$ hybrid has been studied by Hormaza et al., (2012) and Sandra Milena Rincóna, (2013). Macfarlane et al., (1975) had analyzed mesocarp and kernel oils from the oleifera and their progenies. World over about 2.5 million interspecific hybrid seeds are produced every year from Ecuador (CIRAD Partners - 1 million), Colombia (La cabana - 0.3 million, Indupalma 0.2 million) and Brazil (Embrapa - 1 million) for commercial cultivation (Murugesan and Rethinam, 2018). Interspecific hybrid of Brazil namely 'BRS Manicoré' when tested for seed germination showed only 30-35\% germination owing to its wild character (Wanderlei Antônio Alves Lima et al., 2014). The above organizations could establish multi-location trials using the collected materials both in donors and their research stations. A selection cycle that includes evaluation and phenotypic selection and hybridization to produce new progenies requires around 20 years (Corley and Tinker, 2003). Genomic in Situ Hybridization (GISH) developed at Malaysian Palm Oil Board (MPOB) could be utilized to ascertain the amount of introgressed parental genomes into $0 \times G$ hybrids (Madon et al, 1999). This technique can show a clear differentiation between the $E$. oleifera and E. guineensis genome. Singh et al., (2004) sequenced the genome of $E$. guineensis and found to be about 1.8 GB and detected no significant differences between two species. Interspecific hybrids have thin shell but lack fiber ring unlike that of normal hybrids (tenera) developed by crossing dura (thick shell) and pisifera (shell-less) in E. guineensis. Fruit detachment and build-up of free fatty acids are slow in E. oleifera compared to tenera. The yield of the hybrids in terms of total fruit weight was promising, but the oil content of the mesocarp is intermediate between the parental species and lower than in E. guineensis. E. oleifera has a marked tendency towards the production of parthenocarpy fruits and this character was fully dominant in the hybrids. Because of this, the percentage fruits per bunch in the hybrids tend to become greater than in E. guineensis, and this partly helped to compensate for the lower percentage of oil in the mesocarp. Improving oil quality has been implemented by backcross program of $\mathrm{O} \times \mathrm{G}$ hybrids with the best parents from RRS schemes (Edy Suprianto et al., 2016). We need to evaluate the genetic variability of the progenies of oleifera and interspecific hybrids to select best-combining parents (Rui Alberto Gomes et al., 2014).

\section{Elaeis oleifera in India}

There are four oleifera accessions namely, DOPR22 (Suriname), DOPR23 (Malaysia), DOPR24 (Costa Rica), and DOPR25 (Oil Palm India LimitedChithera) available in India (Murugesan, and Sunil Kumar, 2014). They were introduced to India along with commercial planting materials (Murugesan and Sunil Kumar, 2014). Out of four sources, three accessions are available at Palode, Kerala, and another source (two palms) was located at Chithara Estate of Oil Palm India Limited (OPIL), Kerala (Murugesan, 2010). Three accessions planted at Palode have been designated as DOPR G 22, 23, and 24 and evaluated for selection of promising individual palms for further improvement (Murugesan and Shareef, 2014). Interspecific hybridization programme has been undertaken in India with an objective to obtain cultivars with high fruit and oil production per unit of area, low annual height increment, and oil with high content of unsaturated fatty acids and carotenes (Murugesan and Sunil Kumar, 2014). Interspecific hybrids $(O \times G)$ of seven combinations were developed in India utilizing oleifera of DOPR 23 and Palode dura and the progenies were planted during 1998. Three promising dwarf interspecific palms, namely 47 (361Eg $\times 11 \mathrm{Eo}), 48$ (16Eo $\times 18 \mathrm{Eg})$ and 6 (12Eo $\times 82 \mathrm{Eg}$ ) were identified from this field trial (Sunil Kumar et al .,2015). Notably, palm No 48 (genetic stock from one of the above combinations) namely, $160 \times 18 \mathrm{G}$ showed unique characteristics viz., high fruit set, and unique fruit color (deep red skin and yellow mesocarp) apart from compact slow height increment (Murugesan et al., 2019). The evaluation indicated that DOPR G23 and DOPR G24, grow vigorously and with a height increment of 24 and $34 \mathrm{~cm}$, respectively. They also had a rachis length of $6.66 \mathrm{~m}$ in DOPR G23 and $6.24 \mathrm{~m}$ in DOPR G24. DOPR 23 had a height increment of $15 \mathrm{~cm}$ with $6.4 \mathrm{~m}$ rachis length. Leaf area is also considered for screening of germplasm as 
it contribute to photosynthesis (Kalarani et al., 2018). One interspecific palm No. 6 of DOPR 23 with high yield and other desirable characters was alone taken forward to F1 backcrossing programme after evaluation at Palode, Kerala (Murugesan and Shareef., 2014) which recorded highest FFB yield and possessed compact characteristics was ultimately selected for producing interspecific hybrids and further breeding for dwarf palms. E. oleifera from OPIL exhibits all the desirable characters, especially for fruit weight (15.41g), Fruit to Bunch (61.46\%), and height increment $(15 \mathrm{~cm})$. Notably, it has a distinct trait of the large kernel with an average nut weight of $6.95 \mathrm{~g}$ per fruit. Selfed and inter se mated progenies of DOPR 25 were planted during 2010 as an observation trial at Palode and progenies showed precocity for bunch production, with very low height increment and normal fruit set and high sex ratio (Murugesan and Sunil Kumar (2014a) and Murugesan and Sunil Kumar, 2014b). A germplasm accession of Elaeis oleifera of Surinam source showed early fruit ripening and harvestable maturity (4.5 months) under the tropical climate of south India (Murugesan et al., 2011). These Suriname materials were believed to be sourced from Nigeria and the identified palms were located inside the Oil Palm India Limited estate located at Chihara, Kollam district of Kerala (Murugesan, 2010). To get uniform germination and seedlings and to facilitate the precise evaluation of progenies of interspecific hybrids, the mechanical scarification techniques were developed (Murugesan et al., 2015). Notably, four genetic stocks viz., Palm no.45 of Surinam of DOPR 22, Palm No.6 of DOPR G 23, Palm No 48 of DOPR 23 and Palm No.6 of DOPR 25 were developed for improvement and introgression into current Indian breeding programme. Oleifera genetic resources and $O \times G$ hybrids have good prospects for achieving high oil quality, disease tolerance/ resistance, high-density planting, and commercial cultivation. But, India has a very narrow genetic base (Rethinam and Vinod Kumar, 1998) and there is an urgent need to collect new materials from centers of origin by exploration and exchange through unilateral and multilateral collaborative programmes for broadening the genetic base (Murugesan et al., (2016) and Rethinam, 2018).

\section{CONCLUSION}

Oleifera germplasm has been collected from the natural palm grooves of South America and conserved in the field gene banks of Malaysia, Ivory Coast, Costa Rica, Brazil, Colombia, and other oil palm growing countries. Though oleifera is not in cultivation but extensively used in advanced crop improvement programmes as they have desirable traits, viz., slow vertical growth, superior oil quality, and disease tolerance. Interspecific hybrids $(O \times G)$ are produced through the conventional breeding programme for introgression of desirable traits. Several advanced $\mathrm{O} \times \mathrm{G}$ hybrids were developed from different research organizations with a major breeding objective of improving palm oil quality and high-density planting. Replanting $\mathrm{O} \times \mathrm{G}$ hybrids is also undertaken by some oil palm producing countries in view of catastrophic disease spread in the plantation planted with tenera hybrids, especially in South America. Some advanced $\mathrm{O} \times \mathrm{G}$ hybrids are reported to produce high oil yields close to that of tenera of Elaeis guineensis. Interspecific hybridization programme has been initiated in India with an aim to achieve superior palm oil quality with palms suitable for high-density planting. The preliminary evaluation indicated that some individual palms of indigenously developed genetic stocks showed precocity for bunch production and recorded very low annual height increment with normal fruit set and high sex ratio. Four such oleifera genetic stocks and breeding lines are available for further evaluation and improvement. There is an urgent need to introduce targeted germplasm from centres of origin by exploration and exchange through unilateral and multilateral collaborative programmes for broadening the genetic base for the development of new varieties suitable to different agro-climatic conditions of India.

\section{ACKNOWLEDGEMENT}

We thank Director of ICAR-CTCRI, Thiruvanantha puram, Kerala for permission to publish research review. Senior author thanks Dr.A.V.V. Koudinya, Scientist, ICAR-CTCRI for help and support to format the manuscript of the article.

\section{REFERENCES}

Abdul Rahim, M.F., Lee Yang Ping., Mohd Nasruddin Mohamad., Mohd Latif Kamarudin., Mohd Mahfuz Roslan., Naderman Samin., Nur Adibah Ishak., Suthashini kisan Krishna.n, Noor Susilawati Mandangan., Nurul Fatiha Farhana Hanafi., Leao Ling Jiun and Tan Joon Sheong. 2017. FGV Integrated Breeding System (FIBS): Managing Integration of Breeding Data and Operation. Proceedings of the International Seminar on 100 years of technological advancement in Oil Palm Breeding \& Seed Product ion, KLCC, Kulalampur, Malaysia, 83-99

Alvaradoy and R. Escobar, 2017. Seed production and oil palm breeding in Costa Rica, ASD Oil Palm Papers. 47: 19-26.

Amblard, P., Noiret, J.M., Kouamé, B., Potier, F. and B. Adon, 1995. Performances comparées des hybrids interspécifiques et du matériel commercial E. guineensis. Oléagineux. 2: 335-340.

Andrade, E.B. 1983. Relatorio deexpedicao para coleta de germoplasma de caiaue (E. oleifera (H.B.K) Cortes), na Amazonia brasileria. Manaus, EMBRAPA / CNPSD (atual CPAA). 
Arasu, N.T., Laurence, M.J. and N. Rajanaidu. 1987. Prospects for the alteration of fatty acid composition in the oil palm through Breeding. In International Oil Palm/Palm Oil Conference, Kuala Lumpur, Malaysia, 20

Araya, E., Alvarado, A., and R. Escobar 2009. Use of DNA markers for finger printing compact clones and determining the genetic relationship between Elaeis oleifera germplasm origins. ASD. Costa Rica (Agricultural Services \& development -San José, Costa Rica). 21.

Barcelo's, E., Ambler, P., Berthaud, J. and M. Seguin, 2002. The genetic diversity and relationship in American and African oil palm as revealed by AFLP and RFLP molecular markers. Pesquisa Agropecuaria Brasileira. 37: 1105-1114.

Barcelos, E. 2002. Genetic diversity and relationship in American and African oil palm as revealed by RFLP and AFLP molecular markers. Pesquisa Agropecuária Brasileira. Brasília. 37(8): 11051114.

Barcelos, E., Amblard, P. Berthaud, J. and M. Seguim, 2000. The genetic diversity of the American oil palm Elaeis oleifera (Kunth) Cortes revealed by nuclear RFLP markers. In: International Symposium on Oil Palm Genetic Resources and Utilization, 2000, Kuala Lumpur, Malaysian Palm Oil Board, 173-192.

Barcelos, E., Cunha, N.R.W. and B. Nouy, 2005. Genetic resources of oil palm (Elaeis guineensis Jacq and Elaeis oleifera (Kunth) Cortes) available at EMBRAPA and its use. In: Borém, A. and Viana, GV Plant Breeding, Viçosa, UFV. 525.

Barcelos, E., Nunes, C.D.M. and L.B. Cunha, 2000. Breeding and seed production of palm oil trade. In: Viégas, I.J. and Müller, A. A. (Eds). Oil palm cultivation in the Brazilian Amazon. Embrapa Amazônia Oriental, Belém, PA / Embrapa Western Amazon, Manaus, AM. 145 -174.

Cadena, T., Prada, F. A., and H.M. Romero, 2013. Lipase activity, mesocarp oil content, and iodine value in oil palm fruits of Elaeis guineensis, Elaeis oleifera, and the interspecific hybrid O G. J. Sci. Food Agric., 93(3): 674-680.

Chadha, K.L. 2006. Progress and potential of oil palm in India. Report of the Committee to Reassess Fresh Potential Areas of Oil palm in India. Department of Agriculture and Cooperation, Government of India, New Delhi, 216.

Chia GS, Lopes R, Cunha R.N.V, Rocha R.N.C, M.T.G. Lopes 2009. Repetibilidade da produção de cachos de hibridos intere specificos entre American oil palm e dendezeiro. Acta Amazon.,39(2): 249-254.

Choo, Y. M. and B. Yusof, 1996. Elaeis oleifera palm for the pharmaceutical industry. PORIM Information series., 42: 1-4.

Choo, Y. M., Ma, A. N. and S.C, Yap, 1997. Carotenes, vitamin $E$ and sterols in oils from $E$. guineensis, $E$. oleifera and their hybrids. Palm Oil Developments. No. 27: 1-9.

Corley, R. and P. Tinker, 2003. The oil palms. $4^{\text {th }}$ ed. Blackwell Science, Oxford, UK.
Corley, R. H.V. 1982. The genus Elaeis. In: Corley, R. H. V., Hardon, J.J. and Wood, B.J. (eds.) Oil Palm Research. 2nd ed. New York: Elsevier Scientific Publishing Company Inc, 03-05.

Corley, R.H.V. and P.B. Tinker, 2003. The Oil Palm. IVth Edition. In: Selection and breeding. Blackwell Science Ltd. World Agriculture series. 133-215.

Cunha, R.N.V and R.B.R. Lopes, (2010).Manicoré: híbrido interspecific entreocaiauéeodendezeiro African orecomendado para áreas de incidência de amelocemental-fatal. Manaus,(2010). 4p. (EMBRAPA,Amazônia Ocidental.Comunicado Técnico,85).(http://www.snt.embrapa.br/publico/ usuarios/produtos/85-Anexo1.pdf).

De Franqueville H (2003). Review paper: oil palm bud rot in Latin America. Experimental Agriculture. 39: 225-40.

Diana Arias, María González Fausto Prada Iván AyalaDiaz Carmenza Montoya Edison Daza and Hernán Mauricio Romero, 2015. Genetic and phenotypic diversity of natural American oil palm (Elaeis oleifera (H.B.K.) Cortés) accessions. Tree Genetics \& Genomes., 11: 122

Digner Ortega Cedillo, Carlos Felipe Barrera, Eduardo MorilloVelastegui, Leonardo Quintero Roman, Jorge Daniel Ortega, Jorge Orellana Carrera, Victor Cevallos, CaioCesio Salgado, Pedro Crescêncio Souza Carneiro, CosmeDamião Cruz, 2016. Genetic diversity within and between accessions of Elaeis oleifera from the Ecuadorian Amazon. International Journal of Agriculture and Environmental Research. 2(5): 1480-1493

Edy Suprianto, YurnaYenni, NanangSupena, M Arif; Sujadi, Heri A Siregar, Hernawan Y Rahmadi, Sri Wening, Retno D Setiowati, Rokhanah Faizah and Abdul Razak Purba, (2016). Current Status of IOPRI Oil Palm Breeding Program and Seed Production. In: Proceedings of international seminar on oil palm breeding and seed production, (29-30 September 2016), Kisaran, Indonesia. 6.

Hardon, J.J. and G. VTan, 1969. Interspecific hybrids in the Elaeis. 1. Crossability, cytogenetics and fertility of F1 hybrids of $E$. guineensis E. oleifera. Euphytica. 18: 372-379.

Hardon, J.J. 1969. Interspecific hybrids in the genus Elaeis. II. Vegetative growth and yield of F1 hybrids E. guineenisis E. oleifera. Euphytica. 18: 380-388.

Hormaza, P., Mesa-Fuquen, E. and H.M, Romero, 2012. Phenology of the oil palm interspecific hybrid Elaeis oleifera Elaeisguineensis. Sci.Agric. 69(4): 2.

https://nmoop.gov.in

Ibarra-Ruales and Reyes-Cuesta, 2015. Growth in tree nursery of oil palms Elaeis oleiefra Elaeis guineensis and Elaeis guineensis Elaeis guineenisis in Tumaco, Colombia. Corpolca Clenc. Tecnol. Agropecu, Mosquera (Colombia), 16(2): 239-250.

Kalarani, M.K,P. Maheshwari, P and Senthil and M, Umapathi, 2018. Influence of Pre-Flowering Drought on Physiological Parameters and Yield in Groundnut, Madras Agric., J., 105:7-9 
Kanimozhi, T, Shoba, N and K. Venkatesan, 2018. Evaluation of Coconut Hybrids for Tender nut, Madras Agric. J., 105 (7-9): 329-331

Legen, V., Amblard, P., Omore, A., Koutou, A. and J. Meuiner,1991. IRHO Elaeis oleifera Elaeis guineensis interspecific hybrid program. Oleagineux, Corps Gras, Lipides., 46(12): 479-487.

Macfarlane, N, Swetman, T. and Cornelius, J.A. 1975. Analysis of mesocarp and kernel oils from the American oil palm and F1 hybrids with the West African oil palm. J. Sci. Fd. Agric., 26: 1293.

Madon, M., Clyde, M.M. and Cheah, S.C. 1999. Application of genomic in situ hybridization (GISH) on Elaeis hybrids. J. Oil Palm Res., 74-80.

Mohd Din, A., Raja Naidu, N. and Jelani, B.S. 2000. Performance of Elaeis oleifera from Panama, Costa Rica, Colombia and Honduras in Malaysia. Journal of Oil Palm Research., 12(1): 71-80.

Mohini, A., Raja Naidu, N., Kushiro, A., Mahdavi, Y., Mohr Isa, Z. A. and Noh, A. 2002. PS4: High carotene E. oleifera planting materials.MPOB Information Series No. 137. MPOB, Bangy.

Montoya, C., Lopes, R., Flora, A., Cross, D., Cuellar, T., Summon, M. and Ballotter, N. 2013. Quantitative trait loci (QTLs) analysis of palm oil fatty acid composition in an interspecific pseudobackcross from Elaeis oleifera (HBK) Cortés and oil palm (Elaeis guineensis Jacq.) Tree Genetics and Genomes., 9(5): 1207-25.

Moretzsohn, M.C, M.A. Ferreira, Z.P.S. Amaral, P.J.A. Coelho, D. Grattapaglia \& M.E. Ferreira, 2002. Genetic diversity of Brazilian oil palm (Elaeis oleifera H.B.K.) germplasm collected in the Amazon Forest. Euphytica., 124: 35-45, 2002

Murugesan P, K Sunilkumar, R.K. Mathur (2016). International collaboration: Enriching oil palm genetic resource in India. Indian Horticulture.,61(4): 33-36

Murugesan, P and K. Sunil Kumar, 2014a. Enriching oil palm industry through American oil palm. Indian Horticulture., 59(3): 7-9.

Murugesan, $P$ and M. Shareef, 2014. Yield, bunch quality and vegetative traits of American oil palm (Ealey's oleifera, HBK) population in India, Indian J. Hort., 7: 23-27

Murugesan, P and Sunil Kumar K. 2014b. Dwarf oil palm for future generation. Indian Horticulture., 59(6): 10-12.

Murugesan, P, Haseela, H, Shareef M.V.M and S. Gopakumar, 2011. Fruit and seed development in Elaeis oleifera (HBK) Cortes under tropical climate of Kerala. Journal of Plantation Crops., 2011, 39 (1): 73-77

Murugesan, P, RK Mathur, RSN Pillai, K Sunilkumar, D Ramajayam, P Naveenkumar and G Ravichandran, 2019. IC0597690 (DOPR G23-48) (IC0597690; INGR17086), a Dwarf Oil Palm (E. guineensis E. oleifera) Germplasm with $12 \mathrm{~cm}$ Annual Height Increment. High Fruit Set (69.09\%). In. Plant germplasm Registration notice, J. of Plant Genetic Resources., 32(2): 291
Murugesan, P. Enriching oil palm industry,2010. Indian Horticulture.,55(1): 16-18

Murugesan, P., Hazel, H., Jayakumar, S. and M.V.M Shareef, 2011. Fruit and seed development in Elaeis oleifera (HBK) Cortes of Surinam origin. Indian J. Hort., 68(1): 28-30.

Murugesan, P., Ravichandran, G. and Shareef, M. 2015. Effect of mechanical seed scarification on germination and seedling growth of interspecific hybrids of oil palm (Elaeis oleifera). Indian Journal of Agricultural Sciences., 85(3): 374-7.

Noirot, J. M., Wiart, W. 1976. Possibilities for improving the fatty acid composition of palm oil. Oleaginous., 31(11): 465-472.

Ochoa, I. E., Suarez, C.A. and D.G. Canyon, 2013. Desarrollo y maduracion de frutosen Palma de acetize (Ealey's genesis Jacq.) e hybrids O G (E. oleifera $E$. genesis) de palmaUnipalma S.A. Palmas., 34: 326-36.

Omorefe Asemota. and Farida Habib Shah. 2004. Detection of mesocarp oleoyl-thioesterase gene of the South American oil palm Elaeis oleifera by reverse transcriptase polymerase chain reaction. African Journal of Biotechnology., 3(11): 595-598.

Prasad, M.V. 2018. Skill gap in cultivation practices of oil palm (Elaeis guineensis Jacq.), International J. of Oil Palm Research., 10(1\&2): 6-8

Preciado QOA, S Bastidas P, C Betancourth G, E Pena $R$ and R Reyes C, 2011. Harvest prediction and control in interspecific hybrid Elaeis oleifera Elaeis guineensis at Colombian west area of palm production I. Ripeness period determination in order obtain high amounts of oil concentrations at bunches, Corpoica Cienc Tecnol. Agropecu., 12(1): 5-12.

Rajanaidu, A., Kushiro, A. and Mohr-Pin, A. 2017. "Oil palm genetics resources," in Oil palm improvement through the use of genetic resources (Malaysia: Malaysian Palm Oil Board), 221.

Rajanaidu, N, Rao, V. and Kushiro, A. 1989. Genetic analysis of yield, vegetative growth and fatty acid composition (FAC) in interspecific (E. oleifera $E$. genesis) hybrids.In Proceedings of ISOPB/ PORIM Workshop on Prospects of Interspecific Hybrids (Soh, A C and Raja Naidu, N, eds.). p. 28-39.

Rajanaidu, N. 1986. Elaeis oleifera Collection in Central and South America. In Proceeding of the International Workshop on Oil Palm Germplasm and Utilization, Selangor, Malaysia, 84-94.

Rajanaidu, N. 1983. Collection of oil palm (Elaeis oleifera) genetic material in Central and South America. PORIM Bulletin No. 6: 1-11.

Rao, V. and Chang, K. C. 1982. Anthesis and fruit set in Elaeis oleifera (HBK) Cortes. Palm Oil Res. Inst. Malaysia, Bull. 4: 27-34.

Rao, V., Chin Cheuk Weng. and N. Raja Naidu, 1989. Biology and performance of oleifera (HBK) Cortes. Elaeis.,1(2): 109-18.

Renjini VR, Girish K Jha (2019). Oilseeds sector in India: A trade policy perspective. Indian Journal of Agricultural Sciences., 89(1): 73-8. 
Rethinam P and Vinod Kumar (1998). Studies on Interspecific hybridization in Oil Palm. Annual Report 1997-1998, National Research Centre for Oil Palm, Pedavegi- 534 450, West Godavari District, Andhra Pradesh, 18.

Rethinam P, Arulraj S, Rao B.N 2012. Assessment of additional potential areas for oil palm cultivation in India. Report submitted to Department of Agriculture and Cooperation, Ministry of Agriculture, Govt. of India. Directorate of Oil Palm Research, Pedavegi, Andhra Pradesh 184.

Rethinam P. (2018). Perspective role of oil palm in the vegetable oil economy and farmers prosperity in India, SOPOPRAD Publication, 76.

Rethinam, P and P. Murugesan, 2018. Global perspective of germplasm and breeding for seed production in oil palm. International J. of Oil Palm Research., 10(1\&2): 17-34

Rey, L., Gómez, P., Ayala, I., Delgado, W. and P. Rocha, 2004. Coleccionesgenéticas de palma de aceite Elaeis guineensis (Jacq.) y Elaeis oleifera (H.B.K.) de Cenipalma: Características de importancia para el sector palmicultor. Palmas., 25(4): 39-48.

Rivera, Y.D, D.G Cayon S and J.E. and M. Lopez. 2013. Physiological and morphological characterisation of American oil palms (Elaeis oleifera HBK Cortes) and their hybrids (Elaeis oleifera Elaeis guineensis) on the Indupalma plantation. Agronomia Colombiana., 31(3): 314-323

Rocha, P., Prada, F., Rey, L. and I. Ayala, I. 2006. Characterization bioquimica partial de la collection de Elaeis oleifera de cenipalmaproveniente de la Amazonia colombiana. Palmas., 27: 35-44.

Rui Alberto Gomes Jr, Fabio de Lima Gurgela, Leonardo de Azevedo Peixoto, Leonardo Lopes Bhering, Raimundo NonatoVieirada Cunha, Ricardo Lopes, Antônio José de Abreu Pina, Alexandre Sanz Veiga, 2014. Evaluation of interspecific hybrids of palm oil reveals great genetic variability and potential selection gain Industrial Crops and Products.,52: $512-518$

Sambanthamurthi, R., Sundram, K. and Y. Tan, Y. 2000. Chemistry and biochemistry of palm oil. Prog. Lipid Res., 39: 507-558.
Sandra Milena Rincóna, Paola Andrea Hormazab, Leidy Paola Morenoc, Fausto Pradac, DaysyJazmínPortillod, Jesús Alberto Garcíad, Hernán Mauricio Romeroe. 2013. Use of phenological stages of the fruits and physicochemical characteristics of the oil to determine the optimal harvest time of oil palm interspecific O G hybrid fruits. Industrial Crops and Products., 49, 204-210

Singh R, Ong-Abdullah M, and Low E.T, 2004. Oil palm genome sequence reveals divergence of inter fertile species in old and new worlds. Nature. 2013; 500: 335-339. 6.

Sunil Kumar, K, R.K. Mathur, D.S. Sparjanbabu and R.S.N. Pillai, 2015. Evaluation of interspecific oil palm hybrids for dwarfness. J. of Plantation Crops., 43 (1): 29-34

Torres, G. G., Sarria, F., Varon, M., Coffey, M., Elliot. and G. Martinez. 2010. First report of bud rot caused by Phytophthora palmivora on African oil palm in Colombia. Plant Dis., 94(9): 1,163.1

Wanderlei Antônio Alves Lima, Ricardo Lopes, Márcia Green, Raimundo Nonato Vieira Cunha, Samuel Campos Abreu, Alex Queiroz Cysne, 2014. Heat treatment and germination of seeds of interspecific hybrid between American oil palm (Elaeis oleifera (H.B.K) Cortes) and African oil palm (Elaeis guineensis Jacq.). Journal of Seed Science. 36(4): 451-457

Wei Xia., Tingting Luo., Yajing Dou., Wei Zhang., Annaliese, S., Mason., Dongyi Huang., Xiaolong Huang Wenqi Tang Jihua Wang., Chunyu Zhang. and Yong Xiao. 2019. Identification and Validation of Candidate Genes Involved in Fatty Acid Content in Oil Palm by Genome- Wide Association Analysis. Frontier in plant Science, doi: 10.3389/ fpls.2019.01263

Widart, W. and J. P. Gascon, 1975. Study of composition of Elaeis guineensis oil. Possibilities for improvement. Oleagineux., 30(10): 406-409. 